\title{
SAÚdE BUCAL NO PROGRAMA DE EDUCAÇÃo PELO TRABALHO PARA
}

\section{A SAÚDE (PET SAÚDE)}

Juliane Slembarski MACHADO, Susiane Queiroz BASTOS, Marilene da Cruz Magalhães BUFFON, Giovana Daniela PECHARKI, Magda Eline Guerrart PORTUGAL

O PET-Saúde busca aprimorar o ensino de práticas de saúde oferecido a acadêmicos de cursos da área de saúde, incluindo a Odontologia, nas atividades desenvolvidas junto às Unidades de Saúde (U.S.) nos municípios de Curitiba e Colombo. O objetivo é desenvolver ações de prevenção, promoção e recuperação da saúde bucal nos municípios citados. O público alvo é constituído por moradores da área de abrangência das U.S. Foi realizada estimativa rápida em escolares para avaliação de severidade de doença cárie, a fim de possibilitar o planejamento de ações educativas, preventivas e curativas em saúde bucal. Os escolares com alta severidade da doença cárie (três ou mais lesões cariosas) estão recebendo tratamento clínico-restaurador. Para os escolares de baixa, média e alta severidade de cárie são realizadas: palestras com os pais e educadores sobre saúde bucal; atividades lúdicas com as crianças utilizando recursos como música, jogos educativos e teatro de fantoches; orientação em higienização bucal com escovação supervisionada. $O$ programa tem proporcionado ao acadêmico de Odontologia o conhecimento da relação entre a condição de vida da população e seus agravos à saúde bucal, bem como, da organização da atenção à saúde bucal nos municípios de Curitiba e Colombo.

Palavras-chave: Saúde Bucal; Prevenção; Promoção. 